\title{
Evaluation of Rice Genotypes for Their Agronomic Performance and Resistance against Magnaporthe
}

\section{oryzae}

\author{
M. B. Aremu ${ }^{1, *}$, M. Bashir ${ }^{1}$, S. T. Gbadeyan ${ }^{1}$, M. O. Adebola ${ }^{2}$, K. A. Yusuf ${ }^{3}$ \\ ${ }^{1}$ National Cereal Research Institute, Badeggi, Niger State, Nigeria. \\ ${ }^{2}$ Federal University of Technology, Minna, Niger State, Nigeria. \\ ${ }^{3}$ Nigeria Stored Products Research Institute, Ilorin, Kwara State, Nigeria.
}

How to cite this paper: M. B. Aremu, M. Bashir, S. T. Gbadeyan, M. O. Adebola, K. A. Yusuf. (2021) Evaluation of Rice Genotypes for Their Agronomic Performance and Resistance against Magnaporthe oryzae. International Journal of the Science of Food and Agriculture, 5(1), 170-173. DOI: $10.26855 /$ ijfsa.2021.03.021

Received: January 30, 2021

Accepted: February 28, 2021

Published: March 18, 2021

*Corresponding author: M. B. Aremu, Department of Chemistry, National Cereal Research Institute, Badeggi, Niger State, Nigeria.

Email: mariambukola036@yahoo.com

\begin{abstract}
Rice, Oryzae sativa (L.) is an important staple food crop that is widely consumed in Nigeria, however, it is affected by diseases which thus affect the yield. This study was carried out to evaluate rice genotypes for resistance to natural population of blast pathogen and there agronomic performance. Seventeen (17) rice genotypes screened for blast disease resistance caused by Magnaporthe oryzae at the blast hot spot and water stress environment and there agronomic performance at National Cereal Research Institute, Badeggi showed different reactions. Genotype BR3 is highly resistant and has the list incidence of $28 \%$ may be utilized by incorporating it into the breeding programme. BR2 is moderately resistant and also gave the highest grain yield. The blast incidence and severity does not affect the agronomic performance of the rice genotypes as most of the genotypes yield above the average grain yield of 3 tons/hecter. Development of resistant varieties has been the most effective and economical strategy to control blast disease of Magnaporthe oryzae.
\end{abstract}

Keywords

Magnaporthe oryzae, Blast, Agronomic performance, Rice, Genotype

\section{Introduction}

Rice is an extremely important staple food in Nigeria for both rural and urban dwellers in Nigeria [1]. It is consumed across all geo-political zones and socioeconomic classes. Only about $57 \%$ of the 6.7 million metric tonnes of rice consumed in Nigeria annually is locally produced, leading to a supply deficit of about 3 million metric tonnes [1]. Thus, rice is ranked fourth most important cereal crop in terms of production after sorghum, maize and millet [2]. However, rapid growth in the country's population which is estimated to exceed 200 million by 2019 is expected that the demand for rice will be sustained and increased in the foreseeable future.

Nigeria is the largest rice importer in West Africa despite having about 5.0 million hectares of land suitable for rice cultivation [2]. Rice production in Nigeria is faced by several biotic and abiotic limitations, and prominent among the biotic factors is yield loss due to diseases. Among these diseases, leaf blast caused by Magnaporthe oryzae remains a particular threat because of its unpredictable outbreaks as well as breaking down of genes in resistant cultivars over time [3]. Leaf blast is one of the most serious and widespread constraint of rice cultivation in Nigeria, which occurs in upland and rainfed rice field [4]. Water deficiency predisposes the rice field to severe infection in all environments [5]. Currently, the use of pesticides has proven to be successful in the control of this disease to a very large extent, but these results in increase in the cost of production and these chemicals are sometimes not eco-friendly [6]. Therefore, the deployment of blast-resistant cultivars is the main method of combating the disease, because it is considered as a no-cost 
technology especially to the poor farmers [7]. Therefore, the objective of this study focused on field evaluation of seventeen rice genotypes to confirm their resistance to natural population of blast pathogen under water stress environment. The agronomic performance of the rice genotypes and their resistance to diseases will facilitate their selection and incorporation into the breeding programs in Nigeria. It is on this note that the study on evaluation of Rice Genotypes for the Agronomic Performance and Resistance against Magnaporthe oryzae was investigated.

\section{Materials and Methods}

Fifteen NCRI advance rice breeding lines and two released variety (checks) were collected from the breeding unit of the National Cereals Research Institute (NCRI), Badeggi. The study was conducted at hydromorphic field latitude (N9 ${ }^{\circ} .04^{\prime} 02.05$ and longitudes E6 ${ }^{\circ} .01^{\prime} 30.31$ ) of the National Cereals Research Institute, Badeggi, Niger state during 2017 cropping season.

\section{Experimental Design}

The experiment was laid out in a randomised complete block design and replicated 3 times and each entry was planted to a $2 \times 5 \mathrm{~m}^{2}$ plot size. Fertilizer application was 80, 40, $40 \mathrm{~kg}$ per ha of N, P2O5 and K2O, with N applied in two splits at 21 and 42 days after planting. Weed was controlled using propanol and 2-4-D formulation at 4 litres per hectare of Orizo plus with supplementary hand weeding.

The data regarding the occurrence of the blast disease were collected seventh week after planting using the Standard Evaluation System developed by International Rice Research Institute (IRRI, 2013) and then converting into percentage disease by using the formula;

$$
\text { Disease }(\%)=\frac{\text { Average of the disease score } \times 100}{9}
$$

Other data collected include the agronomic traits, yield variables and disease incidence at the appearance of symptoms.

\section{Results and Discussion}

These rice genotypes showed different reactions for response to blast. Scoring of 1 in the susceptible local check (FARO 52) indicated probably that there is genetic mutation of the variety against blast as the environment was suitable for disease screening. There were 2 resistant (R) varieties, 5 moderately resistant (MR) and 9 moderately susceptible (MS) varieties (Table 1). [5], [6] and [8], also observed variation in the reaction of rice genotypes to leaf blast. Significant difference at $5 \%$ level of probability was also observed for percentage blast incidence and blast severity (Table 2). Significant difference at $5 \%$ level of probability was also observed for number of tiller $/ \mathrm{m}^{2}$ and grain weight across the means of all the rice lines evaluated. Means of plant height, panicle $/ \mathrm{m}^{2}, 50 \%$ flowering and grain yield were significantly different at 5\% level of probability (Table 3). Highest number (78.6 and 280) of plant height and tiller/m2 were recorded in BR8 respectively. BR12 recorded the highest number (450g) of panicle/m2 followed by BR6 (431) (Table 3) though has the highest percentage blast incidence $43 \%$ and severity scoring of 5 across all the genotypes (Table 2 and Table 3). The susceptibility of this genotype may be as result of genetic makeup from the parents. Most of the genotypes gave grain yield above 3t/ha, though BR2 significantly at $5 \%$ gave higher grain yield of $6,190 \mathrm{~kg} / \mathrm{ha}$ than all other entries (Table 3). Lowest grain yield was recorded in BR 11.

There was no significant effect of blast infection over the agronomic traits and yield variables of all the rice genotypes evaluated as there was negative correlation between the percentage blast incidence, severity and grain yield of the rice lines (Table 3). Majority of the genotypes yield above 3tons which is the average expected yield under the natural blast infection. The resistant genotype is therefore recommended for incorporation in to the breeding program in Nigeria.

Table 1. Phenotypic Difference to Resistance

\begin{tabular}{cc}
\hline Rice Lines & Blast Host Behaviour \\
\hline BR3 \&FARO 52 & R \\
BR1, BR2, BR4, BR5, BR7 \& BR13 & MR \\
BR6, BR8, BR9, BR10, BR11, BR12, BR14, BR15 \& FARO 44 & MS \\
\hline
\end{tabular}

BR-Breed Rice, R-Resistsnce, MR-Moderately Resistance \& MS-Moderately Susceptible 
Table 2. Blast disease incidence and severity of the rice genotypes

\begin{tabular}{cccc}
\hline Treatment No & Designation & \% Blast Incidence & Blast severity \\
\hline 1 & BR1 & 38 & 4 \\
2 & BR2 & 32 & 2 \\
3 & BR3 & 28 & 3 \\
4 & BR4 & 32 & 2 \\
5 & BR5 & 42 & 5 \\
6 & BR6 & 43 & 2 \\
7 & BR7 & 35 & 4 \\
8 & BR8 & 32 & 4 \\
9 & BR9 & 38 & 4 \\
10 & BR10 & 37 & 4 \\
11 & BR11 & 37 & 4 \\
12 & BR12 & 40 & 3 \\
14 & BR13 & 32 & 4 \\
15 & BR14 & 33 & 4 \\
17 & BR15 & 35 & 4 \\
& FARO 44 & 35 & 37 \\
\end{tabular}

BR-Breed Rice

Table 3. Agronomic performance of rice genotypes/varieties under natural field infection of Blast pathogen (Magnaporthe oryzae) at NCRI hydromorphic field, Badeggi

\begin{tabular}{|c|c|c|c|c|c|c|c|}
\hline $\begin{array}{l}\text { Treatment } \\
\text { No }\end{array}$ & Designation & $\begin{array}{l}\text { Plant } \\
\text { Height }\end{array}$ & $\begin{array}{l}\text { Tiller } \\
\text { No/m }{ }^{2}\end{array}$ & Panicle/m² & $\begin{array}{l}50 \% \text { Flower- } \\
\text { ing }\end{array}$ & $\begin{array}{l}1000 \text { Grain weight } \\
\text { (g) }\end{array}$ & $\begin{array}{l}\text { Grain Yield } \\
\quad(\mathrm{kg})\end{array}$ \\
\hline 1 & BR1 & 56.1 & 207 & 371 & 62 & 23 & 3,443 \\
\hline 2 & BR2 & 59.8 & 228 & 414 & 63 & 23 & 6,190 \\
\hline 3 & BR3 & 51.3 & 260 & 390 & 62 & 23 & 3,837 \\
\hline 4 & BR4 & 65.7 & 227 & 413 & 84 & 27 & 4,387 \\
\hline 5 & BR5 & 59.9 & 217 & 431 & 90 & 23 & 3,033 \\
\hline 6 & BR6 & 61.3 & 217 & 377 & 79 & 23 & 4,443 \\
\hline 7 & BR7 & 71.4 & 240 & 403 & 77 & 27 & 3,080 \\
\hline 8 & BR8 & 78.6 & 280 & 383 & 90 & 23 & 3,730 \\
\hline 9 & BR9 & 58 & 253 & 398 & 75 & 27 & 2,990 \\
\hline 10 & BR10 & 69.7 & 232 & 433 & 66 & 23 & 1,650 \\
\hline 11 & BR11 & 58.4 & 212 & 450 & 70 & 30 & 4,200 \\
\hline 12 & BR12 & 61.5 & 255 & 424 & 75 & 23 & 3,133 \\
\hline 13 & BR13 & 54.9 & 220 & 422 & 66 & 23 & 3,123 \\
\hline 14 & BR14 & 64.4 & 308 & 400 & 70 & 30 & 3,243 \\
\hline 15 & BR15 & 49.9 & 163 & 342 & 64 & 20 & 3,160 \\
\hline 16 & FARO 44 & 59.6 & 237 & 413 & 64 & 27 & 3,167 \\
\hline \multirow[t]{3}{*}{17} & FARO 52 & 54 & 259 & 374 & 72 & 30 & 4,313 \\
\hline & Lsd 5\% & 13.3618 & 81.856 & 45.426 & 4.19056 & 9.53087 & 175.833 \\
\hline & CV\% & 13.2 & 20.8 & 6.8 & 3.7 & 22.8 & 2.9 \\
\hline
\end{tabular}




\section{References}

[1] Obi, G., Adama, M., Odukale, T., Emezie-Ezigbo, I., Funsho, A., and Onaiwu, E (2019). Rice Industry Review. Home.kpmg/ng.1-37.

[2] Oluroubi, R. (2019). Nigeria seen as a biggest rice buyer 2019, behind China. Bloomberg Business.www.bloomberg.com/news.

[3] Anushree, P. U., Naik, Setbhai, R. O., Galkwad, A. P., and Nimbalkar, C. A. (2016). Differential biochemical response of rice (Oryza sativa.L) genotypes against Rice blast (Magnaporthe oryzae). Biochemistry and Structural Biology, 2(1264162).

[4] Aremu, M. B. and Adebola, M. O. (2017). Invitro evaluation of fungicidal resistance of rice blast pathogen (magnaporthe oryzae) strains. Nigeria Journal of Mycology, 9(129-138).

[5] Li, W., Chern, M., Yin, J., Wang, J., and Chen, X. (2019). Recent advances in broad spectrum resistance to the rice blast disease. Current Opinion in Plant Biology, 50(114-120)

[6] Abedi, F., Babaeiyan, N., and Moumeni, A., (2012). Performance of different rice genotype against blast pathogen through linked molecular maker. Journal of Crop Science and Biotechnology.

[7] Adebola, M. O., Ayeni, O. B., and Aremu, M. B. (2018). Evaluation of leaf extracts of four plant species against Rice blast pathogen (Magnaporthe oryzae). Nigeria Journal of Mycology, 10, 88

[8] Zewdu, Z., Gilbson, P. T., Lamo, J., and Edema, R. (2017). Reaction of introduced Korean rice genotype for resistance to rice blast in uganda. Journal of Plant Breeding and Crop Science, 9(7), 98-105. 